\title{
Detection of bovine corona virus in some governorate of Iraq
}

Kh. A. Mansour

Coll. of Vet./Unive. of Al -

Qadisyia
S. A. Hasso

Coll. of Vet./Unive. of

Baghdad
M. N. Al Rodhan

Coll. of Vet./Unive. of Al -

Qadisyia

\section{Abstract}

In the present study we used Reverse transcription polymer chain reaction (RT-PCR) assay for detecting of bovine corona virus, We evaluated presence of bovine corona virus ( $\mathrm{BCoV})$ in diarrheic fecal samples in age $(1$ - 30)day . (152) faecal samples from diarrheic calves were collected from four Iraqi governorates (Al-Qadisyia, Babylon, Wassit and Najaf) .10 (6.57\%) out of 152 were positive to bovine corona virus. This study is the first detection of bovine corona antigen in Iraq .The results suggest that RT-PCR is more sensitive than other method to detect $\mathrm{BCoV}$, especially in subclinical cases and Because these animals shed a low amount of virus in faeces and more animal show clinically normal we need to apply sensitive techniques, such as RT-PCR .

\section{Key word: bovine corona virus, BCoV., RT.PCR}

\section{Introduction}

Bovine Coronavirus (BCoV), a member of the family Coronaviridae, order Nidovirales (1)The Animal coronaviruses are divided into 3 antigenic groups: Group 1 has no hemagglutinin-esterase (HE), and important members of this group are feline infectious peritonitis and transmissible gastroenteritis virus in swine; Group 2 has $\mathrm{HE}$ and contains $\mathrm{BCoV}$; and Group 3 contains avian virus-like infectious bronchitis (2) Coronaviridae comprises at least two genera. One, the genus Coronavirus, contains a substantial number of pathogens of mammals and birds that individually cause a remarkable variety of diseases, Bovine coronavirus infections are associated with three distinct clinical syndromes in cattle: calf diarrhea, winter dysentery (hemorrhagic diarrhea) in adult cattle, and respiratory infections in cattle of various ages, including the bovine respiratory disease complex (shipping fever) in feedlot cattle (3) . Coronaviruses were first reported as a cause of diarrhea in calves in the United States in 1973. (4) in other report showed that the Coronaviruses are responsible for a number of economically important diseases. Avian infectious bronchitis virus (IBV) was the first coronavirus to be isolated, from the domestic

*Sited from MSc. Thesis of the first researcher fowl, and propagated in the 1930s ( 5). Transmission of infection occurs by the fecal-oral route is the presumed method of transmission but aerosol transmission may also occur. Bovine coronavirus causes diarrhea in both dairy and beef calves world wide ranging in age from 1 day to 3 months of age but mostly between 1 and 2 weeks of age. In young calves Disease is more common during the winter months, which may reflect enhanced survival of the virus in a cool, moist environment. The coronavirus may be present in both diarrheic and healthy calves; the incidence rates range from 8-69\% and $0-24 \%$ for diarrheic calves and healthy calves, respectively( 6) There are different methods to detect $\mathrm{BCoV}$, but a high degree of sensitivity is required, especially in subclinically infected calves and chronic shedders of BCoV in faeces( 7). The RTPCR assay is useful to detect small quantities of nucleic acid and is widely used for the diagnosis of infectious disease. The aim of this study to determine the prevalence of bovine coronavirus in instance of calves' diarrhea in some Iraqi governorate.Materials and methods.Collection of sample.A total of (152) fecal samples were collected from diarrheic calves, aged from 1 day to four 


\section{$\begin{array}{llll}\text { AL-Qadisiya Journal of Vet.Med.Sci. } \quad \text { Vol./12 } & \text { No./1 }\end{array}$}

weeks this sample collected from four governorate during winter month . for collection of feces, rectal stimulation was made for the calves then collected directly in to disposable closed plastic container, transported under cold condition were the required tests were done or stored at -20 $C^{0}$.RNA extraction .RNA from faeces was extracted using AccurZol virus RNA mini kit (Bioneer)as instructed by the manufacturer. RNA was extracted with TRIzol LS reagent (Invitrogen) according to the manufacturer's instructions. Briefly, 250 $\mu \mathrm{l}$ of sample material was mixed with $750 \mu \mathrm{l}$ of TRIzol and incubated for $5 \mathrm{~min}$ at room temperature. Thereafter, $200 \mu \mathrm{l}$ of chloroform was added and the combination was mixed. Following centrifugation at 12 $000 \mathrm{~g}$ for $15 \mathrm{~min}$, the aqueous phase was transferred to a new tube with $500 \mu \mathrm{l}$ of isopropanol and incubated overnight for RNA precipitation at $-20^{\circ} \mathrm{C}$. After centrifugation for $20 \mathrm{~min}$ at $4^{\circ} \mathrm{C}$ and washing with $1 \mathrm{ml}$ of cold $75 \%$ ethanol, the pellets were air dried, resuspended in $30 \mu \mathrm{l}$ of dimyristoylphosphatidylcholine (DMPC) water, and stored at $-20^{\circ} \mathrm{C}$. RT-PCR master mix Detection of BCoV RNA was carried out using Accurpower, rocket script RTPCR virus RNA mini kit (Bioneer)as instructed and primers specific for the $\mathrm{N}$ gene protein that are able to detect $\mathrm{BCoV}$. (8). Table(1)

Table(1) : RT-PCR master mix

\begin{tabular}{|l|l|l|}
\hline \multicolumn{2}{|l|}{ RT-PCR master mix } & Volume \\
\hline Viral RNA template & $2 \mu \mathrm{L}$ \\
\hline \multirow{2}{*}{ Primers } & F.Primer & $1.5 \mu \mathrm{L}$ \\
\cline { 2 - 3 } & R.Primer & $1.5 \mu \mathrm{L}$ \\
\hline PCR water & $15 \mu \mathrm{L}$ \\
\hline Total & 20 \\
\hline
\end{tabular}

Preparation of oligonucleotide primers. The oligonucleotide primers used in the RTPCR were designed according (9) sequence of $\mathrm{N}$ gene of Mebus strain (Gen Bank accession No.M16620). The sequence of primers were as follows: upstream primer: 5'-GCA ATC CAG TAG TAG AGC GT-3' (21-40), downstream primers: 5'-CTT AGT GGC ATC CTT GCC AA-3' (731-750). The predicted RT-PCR product size was 730
bp.RT-PCR thermocycles conditions. Detection of BCoV RNA was carried out using Accurpower rocket script RT-PCR virus RNA mini kit (Bioneer)as instructed .The following thermal protocol was used table (2) reverse transcription. The PCR products were detected by electrophoresis through a $1.5 \%$ agarose gel and visualisation under UV light after bromide ethidium staining.

Table(2) RT-PCR thermocycles conditions

\begin{tabular}{|l|l|l|}
\hline Primer step & Universal primer & Number of cycles \\
\hline cDNA synthesis & $45^{\circ} \mathrm{C} 30 \mathrm{~min}$ & 1 \\
\hline Predenaturation & $95^{\circ} \mathrm{C} 5 \mathrm{~min}$ & 1 \\
\hline Denaturation & $95^{\circ} \mathrm{C} 5 \mathrm{~min}$ & 35 \\
\hline Annealing & $57^{\circ} \mathrm{C} 30 \mathrm{sec}$ & 35 \\
\hline Extension & $72^{\circ} \mathrm{C} 40 \mathrm{sec}$ & 35 \\
\hline Final extension & $72^{\circ} \mathrm{C} 5 \mathrm{~min}$ & 1 \\
\hline
\end{tabular}




\section{Result and discussion}

clinical signs of bovine corona virus . In the present study most calves showed different clinical singes, including diarrhea with or without flask of blood ; The feces were pale yellow, mucoid, A yellow to blood-stained mucus, profuse watery diarrhea, and other clinical signes severe dysentery, dehydration, loss of weight ,depression and these signes were similar to study (10). This study showed the presence of coronavirus, in fecal sample from diarrheic and were the causative agents in neonatal calf diarrhea.this results agreed with (11) whom by other techniques detected of bovine corona and rota virus and is agreement with (12) using techniques(one step PCR) to detect bovine corona virus. Detection of corona virus antigen by using one step RT-PC .In the present study we used one step RT-PCR assay for detecting small quantities of $\mathrm{BCoV}$, using a universal primer to detect and target the $730 \mathrm{bp}$ fragment of the nucleocapsid $(\mathrm{N})$ gene of $\mathrm{BCoV}$ and amplify the BCoV strains. We detected the presence of $\mathrm{BCoV}$ in diarrheic samples. Figure (1). In the present study a universal published primer for the detection of the $\mathrm{N}$ gene( nucleocapsid gene) that was conserved among BCoV strains was used, When we used the one step RT-PCR method we observed that the of the specific gene increased. RT-PCR bovine corona virus was execrated in $6.57 \%$ of tested bovine fecal samples from clinically infected calves which is in contrast to other studied from other countries which were as low as $(3.9 \%)$ to ( 8-69\%), (13 and 14 ).Figure (1): Agarose gel electrophoresis image showing the positive results of Bovine Corona Virus in RT-PCR, where M: DNA marker (100$2000 \mathrm{bp}$ ), and 1-10 positive results of BCV primer at specific RT-PCR product size (730bp).

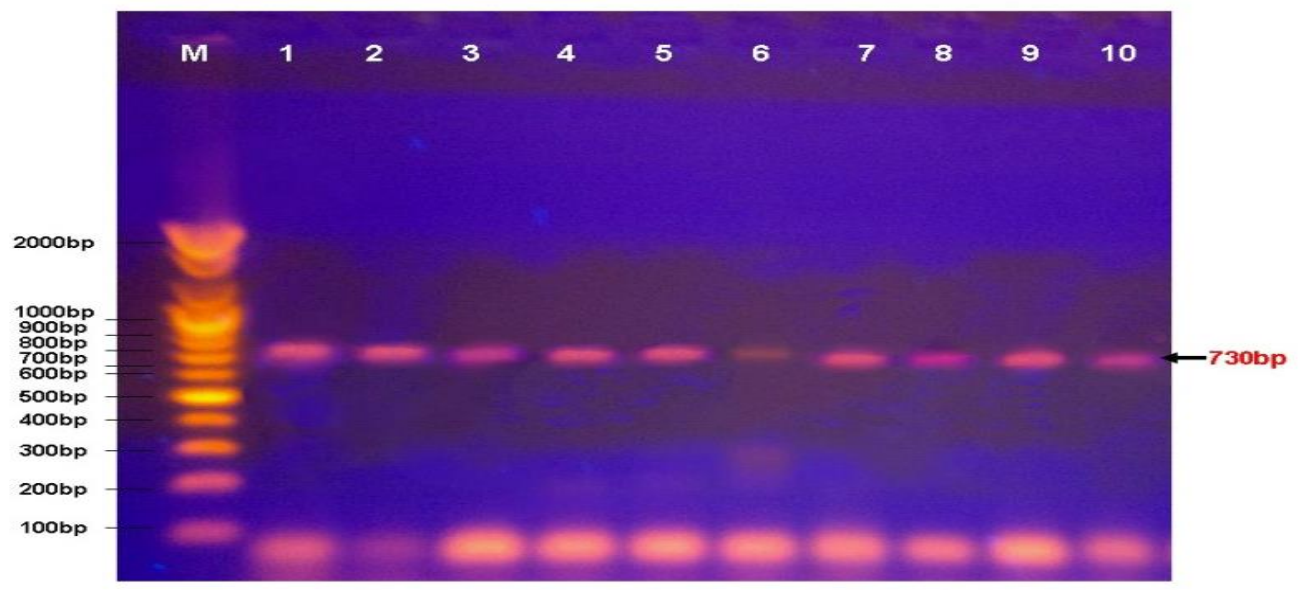

\section{Reference}

1. Vries, A.; A. F., Horzinek, M. C.; Rottier, P. J.M. and Groot, R. J. (1997). The genome organization of the Nidovirales: Similarities and differences between Arteri- Toro-, and Coronaviruses. Semin. Virol.; 8, 33-47.

2. Hasoksuz, M.; Vlasova, A.and Saif, L.J.( 2008). Detection of group $2 \mathrm{a}$ coronaviruses with emphasis on bovine and wild ruminant strains. Virus isolation and detection of antibody, antigen, and nucleic acid. Methods Mol. Biol.;454:43-59.

3. Quinn, P. J.; Markey, B. K.; Carter, M. E. ; Donnelly, W. J. and Leonard, F. C. (2002). Veterinary Microbiology and Microbial 
$\begin{array}{llll}\text { AL-Qadisiya Journal of Vet.Med.Sci. } & \text { Vol./12 } & \text { No./1 }\end{array}$

Diseases. 1st ed., Blackwell Science publishing. P p: 419-420.

4. Maclachan, N. j. and Dubovi, E.J.(2011) Coronaviridae. Fenner's Veterinary Virology.(ED.),P:394- 413.

5. King, D. J., and Cavanagh, D. (1991). Infectious bronchitis. In "Diseases of Poultry" (B. W. Calnek, H. J. Barnes, C. W. Beard, W. M. Reid, and H. W. Yoder, eds.), pp. 471484. Iowa State University Press, Ames.

6. Radostitis, O.M.; Gay, C.C.; Hinchcliff, K.W. and Constable, P.D. (2007). Veterinary Medicine, A textbook of the diseases of cattle, horses, sheep, pigs, and goats, 10th edn. SaundersElsevier, Philadelphia., pp: 12861296.

7. Hasuksuz, M., Hoet, A. E.; Loerech, S. C. ; Wittum, T. E. ; Nielsen, P. R. and Saif L. J.(2002): Detection of respiratory and enteric shedding of bovine coronavirus in cattle in an Ohio feedlot. J. Vet. Diagn. Invest.; 14: 308-313.

8. Erles, K.; Toomey, C.; Brooks, H.W.and Brownlie, J.( 2003). Detection of a group 2 coronavirus in dogs with canine infectious respiratory disease. Virology; p:310, 216-223.

9. Khalili1, M.; Morshedi, H.; Keyvanfar, H.; and Hemmatzadeh, F.(2006). Detection of bovine coronavirus by RT-PCR in a field study. Vet. Arhiv.;76: 291-296.

10. Carman, P.S .and Hazlett, M. J. (19901991). Bovine coronavirus infection in Ontario. Can .Vet. J.;33 (12): 812-4.

11. Athanassious, R.; Marsolais,G.; Assaf, R.; Dea,S.; DescOteaux,J. P.; Suzanne Dulude, S. and Montpetit, C.(1994) Detection of bovine coronavirus and type A rotavirus in neonatal calf diarrhea and winter dysentery of cattle in Quebec: Evaluation of three diagnostic methods. Can Vet J .; 35: 163-169.

12. Zhe, W.; Dong, J.; Haga, T.; Goto, Y. and Sueyoshi, M. (2010). Rapid and Sensitive Detection of Bovine Coronavirus and Group A Bovine Rotavirus from Fecal Samples by Using One-Step Duplex RT-PCR Assay. J. Vet. Med. Sci.; 73(4): 531-534.

13. Park1, S. J.; Lim, G. K.; Park, S. I.; Kim, H. H.; Koh1, H. B. and Cho, K. O. (2007). Detection and Molecular Characterization of Calf Diarrhoea Bovine Coronaviruses Circulating in South Korea during 2004-2005. Journal compilation Blackwell Verlag. Zoonoses. Public Health.; (54): 223-230 .

14. Lathrop, S. L.; Wittum, T. E.; Brock, K. V.; Loerch, S. C. Perino, L. J. ; Bingham, H. R.; McCollum, F. T. and Saif, L. J. ( 2000). Association between infection of the respiratory tract attributable to bovine coronavirus and health and growth performance of cattle in feedlots. Am. J. Vet. Res.; 61: 1062-1066. 
$\begin{array}{llll}\text { AL-Qadisiya Journal of Vet.Med.Sci. } \quad \text { Vol./12 } & \text { No./1 }\end{array}$

\section{تثخيص فايروس bovine corona virus في بعض محافظات العراق}

محسن نعمة الروضان المبان

كلية الطب البيطري/جامعة القادية البية

\author{
سليم أمين حسو \\ كلية الطب البيطري/جامعة بغداد
}

خليفة علي منصور

كلية الطب البيطري/جامعة القادية

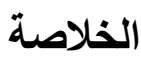

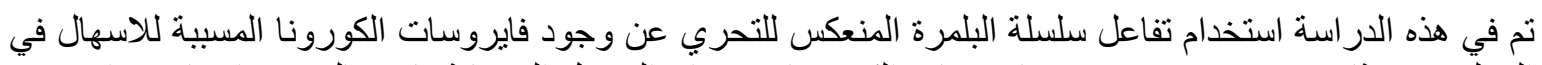

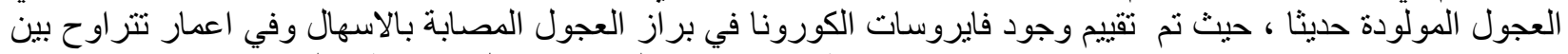

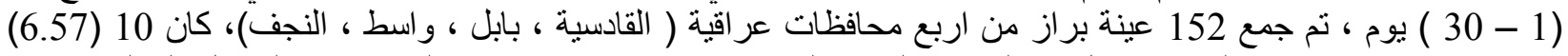

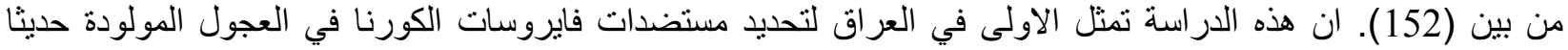

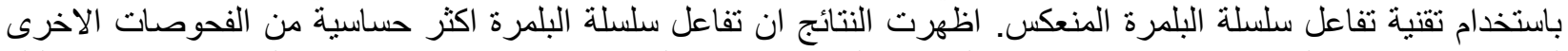

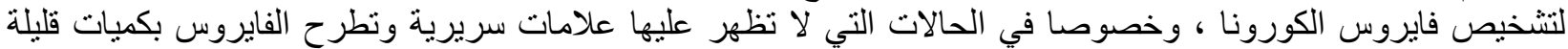

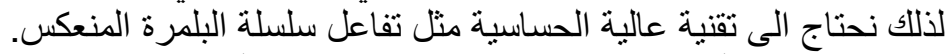
الكلمات المفتاحية: فايروسات الكورونا، تفاعل سلسلة البلمرة المنعكس للتحري 